\title{
Review of Hélène Landemore's Open Democracy: Reinventing Popular Rule for the Twenty-First Century. Princeton, NJ and Oxford: Princeton University Press, 2020, xviii + 243 pp.
}

\section{ERICA YU}

\section{Erasmus University Rotterdam}

Open Democracy is a bold exploration of how we can move beyond a purely electoral conception of democratic representation. Using normative democratic theory and real-world examples of innovations in citizen representation, Hélène Landemore argues for a vision of democracy that is more faithful to popular rule, more likely to tap into democratic reason, and more stable and durable than electoral democracy.

The book begins with the all-too-familiar observation that "democracy is in crisis, or so we are incessantly told" (xiii). The symptoms of this crisis include a decline in voter turnout, the decline of parties as vehicles for mass participation, polarization, extremism, and populism (26-27). Landemore seeks to answer two important questions about this so-called crisis of democracy: How did we get here, and how do we get out? On the first question, Landemore provides a simple answer: representative democracy - characterized by electoral representation-has failed to deliver on the democratic promise of popular rule. On the second question, Landemore develops an ambitious proposal for an 'open democracy' which will bring power back to the people through novel (that is, non-electoral) forms of democratic representation based on random and self-selection.

After an introductory chapter, Landemore develops her claim that the crisis of democracy can be traced to representative democracy being designed on the basis of electoral premises. The crisis that we face, she argues, is not merely the result of external shocks such as globalization, technological change, or the rise of economic inequalities brought about by capitalism. After all, we see that representative democracies are not completely powerless in the face of these challenges. ${ }^{1}$ More fundamen-

\footnotetext{
${ }^{1}$ Landemore argues that the fact that different policies lead to different outcomes in different countries shows that representative democracies have the capacity to deal with these external shocks (32).
} 
tally, representative democracy seems to systematically fail to meet citizens' expectations as to how these problems should be addressed. The crisis, then, seems to come from a problem which is internal to representative democracy.

"The main problem", Landemore argues, "is that representative democracy was designed on the basis of electoral premises" (25). Elections separate out a set of individuals who are deemed 'fit to rule' from the rest of the citizenry. These individuals are then given opportunities to participate in collective deliberations and decisions about public policy, while the ordinary citizen is effectively excluded from these processes. Even with guarantees of full enfranchisement and no restrictions on who can run for office, representative democracy fails to deliver on the democratic promise of popular rule-defined as a regime where all members of society are equally able to participate in all processes of collective deliberation and decision about public policies (33).

This gives rise to two undesirable effects. First, basing representative democracy on elections "limits [its] epistemic potential" (25). This follows from Landemore's epistemic argument for democracy: all things being equal, the rule of the many is at least as good as, and occasionally better than, the rule of the few at identifying the common good and providing solutions to collective problems $(2012,3)$. $^{2}$ As electoral representation entails a 'rule of the few', its epistemic potential is limited.

Second, elections result in partisan politics which are not conducive to deliberation. The principle of periodic elections entails that parties have to regularly compete with each other and differentiate themselves in terms of the values and interests that they claim to promote. This competitive environment leads to partisanship and a lack of willingness to cooperate with other parties, which goes against the deliberative virtue of open-mindedness.

The solution, then, is to open up the entire decision process to all citizens. Shall we then turn to direct democracy, which is becoming easier to implement through digital technologies? ${ }^{3}$ In chapter 3, Landemore argues that we should not. Direct democracy is not able to deal with the scale problem of deliberative democracy: "deliberative decisions appear to be illegitimate for those left outside the forum, while bringing in more

\footnotetext{
${ }^{2}$ Landemore (2012) argues that this is so because including more people in a decisionmaking process increases cognitive diversity, which has been shown to lead to better outcomes in problem-solving and prediction problems (Hong and Page 2004).

${ }^{3}$ See Lindner and Aichholzer (2020) for a recent introductory overview of the theoretical and conceptual foundations of electronic democracy.
} 
than a few people in would quickly turn the event into speech-making, not deliberation" (Parkinson 2003, 181; my emphasis). Representation is still essential in order to have deliberation that is both democratic and able to meet certain procedural standards. We do not need to dispense with representation, but to radically rethink it.

In chapters 4 and 5, Landemore explores the potentials of lottocratic and self-selected representation to deliver on the democratic promise of popular rule. Lottocratic representation is based on random selection: all citizens are given an equal chance to be selected as a representative through lotteries. Self-selected representation is based on individuals choosing to become a representative. Landemore argues that both lottocratic and self-selected representation are more democratic and can be at least as legitimate as electoral representation.

A form of representation is democratic to the extent that access to the assembly is inclusive and equal. Electoral representation, on the one hand, presents significant barriers to entry to positions of power by privileging a certain political elite. Lottocratic representation, on the other hand, rests on a strict principle of equality and impartiality between citizens (90): all have an equal chance to be chosen to represent their fellow citizens, no matter who they are. Even self-selected representation is more democratic than electoral representation as it is open in a way that electoral representation is not: anyone who wants to become a representative can become one.

A form of representation is legitimate to the extent that representatives are deemed morally entitled to make binding decisions for the rest of the polity. The legitimacy of electoral representation rests on citizens authorizing the transfer of their power to their representatives through the votes that they cast. Similarly, lottocratic and self-selected representation can be legitimized through the authorization of the mechanisms of selecting representatives by at least a majority of those to be represented.

Having shown that lottocratic and self-selected representation are more democratic and at least as legitimate as electoral representation, Landemore then formulates a new conception of representative democracy based on these new notions of representation in chapter 6 which she calls 'open democracy'. Open democracy is defined according to five institutional principles. Participation rights ensure actual access to power instead of mere opportunities to provide or withdraw consent. Deliberation is a process which must involve all participants (either directly or indirectly), and not just gifted orators. The majoritarian principle ensures 
that where deliberation fails to produce consensus, disagreements are able to be resolved. Democratic representation is not necessarily defined in electoral terms in open democracy, but it "embraces a richer ecology of various forms of democratic representation" (142) such as in lottocratic and self-selected terms. It is important to note, however, that the central form of democratic representation advocated for by Landemore is lottocratic. Finally, transparency ensures that citizens are aware of the responsibilities and duties of their representatives and can hold them to account.

Chapter 7 then explores how the Icelandic constitutional reform process from 2010 to 2013 shows how open democracy can be implemented, what its demonstrated benefits are, and what lessons we can learn. Most significantly, Landemore argues that the high levels of public participation through lottocratic representation and crowdsourcing resulted in more expansive rights provision in the drafted constitution as a greater number of interests and perspectives were taken into account.

Chapter 8 then deals with various challenges that can be put forward concerning the viability of open democracy. The most serious of these challenges include the feasibility of open democracy in big and heterogenous countries, and the lack of competence and accountability of nonelected representatives.

Landemore concludes by offering a concrete vision of what an open democracy could look like:

[The open] mini-public is an all-purpose, randomly selected body open to the input of the larger public via citizen initiatives and rights of referral as well as a permanent online crowdsourcing and deliberative platform, and ultimately connected to a demos-wide referendum on central issues [...]. This general purpose mini-public would form the center of a network of other mini-publics, some of them single-issue, others generalist, operating at various sub-levels of the polity. Combined, they would form a web of connected mini-publics all staffed with randomly selected citizens. (218-219)

Landemore has written a thoughtful and engaging appraisal of representative democracy which engages with both ideal theory and not-always-ideal real-world cases. It is noteworthy how Open Democracy does not shy away from engaging with skeptics of both, normative theory and practical implementation. Landemore does not only want to convince those who already think that randomly-selected deliberative mini-publics 
are essential for democracy, but also those who stand by elections as the constitutive feature of democracy.

Landemore coherently and convincingly argues that representative democracy based on electoral representation fails to deliver on the democratic promise of popular rule, as its fundamental design is based precisely on drawing a distinction between the rulers and the ruled. That being said, there are two concerns which call into question whether lottocratic representation-which Landemore argues should be the central form of representation in open democracy - is indeed better able than electoral representation to achieve popular rule and enjoy its purported benefits.

The first point concerns Landemore's argument for lottocratic representation being more democratic than elections: "Given enough rotation and a small enough population, actual access to power is strictly equalized over the long term" (90). However, as Landemore rightly points out, this implies that lottocracy's advantage over elections depends on there being a large number of seats available and frequent enough rotation to ensure that the chance of being selected as a lottocratic representative is greater than the chance of the average citizen being elected into office (91). Her solution is then to increase opportunities to be selected for a lottocratic assembly by combining a lottocratic assembly at the national level with the creation of a multiplicity of local assemblies that set the agenda for the national one (92).

However, Landemore now needs to weigh the benefits of achieving actual (and not merely hypothetical) equalization of access to power with the costs entailed by putting up these multiple localized assemblies. If, for example, the marginal costs of putting up a lottocratic localized assembly exceed its marginal benefits in terms of its contribution to the quality of collective decisions, would it still be worth pursuing in order to achieve actual equalization of access to power? If Landemore argues that it is, then her commitment to the instrumental value of democracy in terms of its epistemic benefits is compromised. If she argues that it is not, then the case for lottocratic representation being more democratic than electoral representation is weakened as there is no guarantee that the chance of being selected as a lottocratic representative is always greater than the chance of the average citizen being elected into office.

The second point is that lottocratic representation may fail to bridge the distance between the rulers and the ruled because these forms of representation still do not address the underlying lack of interest of citizens 
to engage in making decisions for the rest of the polity. ${ }^{4}$ Some of the symptoms of the crisis of democracy that Landemore points to include declining voter turnout and party membership. Thus, citizens are already choosing not to exercise their already little power over collective decisions in an electoral democracy. Simply giving them more opportunities to influence these decisions does not mean that they will choose to undertake the responsibilities of representatives.

This has been illustrated in the case of an experiment done in Rotterdam where neighborhood councils were formed by selecting representatives by lot (van Buuren et al. 2020). These councils were supported by civil servants who were tasked with providing information and advice to the representatives. A key observation in this experiment was that the civil service support ended up doing most of the actual decision-making work on behalf of these lottocratic representatives because of their lack of confidence in their knowledge, skills, and connections to make these decisions themselves (van Buuren et al. 2020, 26). ${ }^{5}$

Perhaps lottocracy is merely a 'shortcut' to a democracy which is able to deliver on its promise of popular rule, as Lafont (2019) argues. Though Landemore is right to move away from Lafont's push for full mass participation, she still has to engage with Lafont's key claim that a necessary condition for popular rule (or, in Lafont's words, "self-government") entails that "all citizens can equally own and identify with the institutions, laws, and policies to which they are subject" (Lafont 2019, 3; my emphasis). Without empowering citizens to actually take charge of collective decisions, lottocratic and self-selected representation are not able to guarantee this.

To conclude, Open Democracy provides a much-needed radical rethinking of democratic representation. It engages deeply with normative democratic theory and real-world examples of innovations in democratic representation. However, more needs to be done in order to argue that open democracy-with lottocratic representation at its core-delivers on the promise of popular rule to a greater extent than electoral democracy.

\footnotetext{
${ }^{4}$ Whether or not this lack of interest and engagement is due to electoral democracy is beside the point. The mere availability of opportunities to participate in collective decision-making is not enough to guarantee that people will actually participate.

${ }^{5}$ This case is particularly interesting as these lottocratic representatives were given access to the relevant expertise, but still chose to delegate their decision-making power to these experts instead of being empowered to make the decisions themselves.
} 


\section{REFERENCES}

van Buuren, Arwin, Ingmar van Meerkerk, Floris Hager, Wijnand Kerklaan, Marn van Rhee, Lucy van Eck, and Karlijn Schipper. 2020. "Adviesnotitie Lerende Evaluatie Bestuursmodel Rotterdam 2018-2022." Erasmus Universiteit Rotterdam, December 18, 2020. https://rotterdam.raadsinformatie.nl/document/9673777/1/ s21bb000426_3_45964_tds.

Hong, Lu, and Scott E. Page. 2004. "Groups of Diverse Problem Solvers Can Outperform Groups of High-Ability Problem Solvers." Proceedings of the National Academy of Sciences 101 (46): 16385-16389.

Lafont, Cristina. 2019. Democracy Without Shortcuts: A Participatory Conception of Deliberative Democracy. Oxford: Oxford University Press.

Landemore, Hélène. 2012. Democratic Reason: Politics, Collective Intelligence, and the Rule of the Many. Princeton, NJ: Princeton University Press.

Lindner, Ralf, and Georg Aichholzer. 2020. "E-Democracy: Conceptual Foundations and Recent Trends." In European E-Democracy in Practice, edited by Leonhard Hennen, Ira van Keulen, Iris Korthagen, Georg Aichholzer, Ralf Lindner, and Rasmus Øjvind Nielsen, 11-45. Cham: Springer.

Parkinson, John. 2003. "Legitimacy Problems in Deliberative Democracy." Political Studies 51 (1): 180-196.

Erica $\mathrm{Yu}$ is a $\mathrm{PhD}$ candidate in philosophy at Erasmus University Rotterdam. Her research interests lie in the intersection of social choice theory, deliberative democracy, and political representation.

Contact e-mail: <yu@esphil.eur.nl> 